\title{
Mechanical distribution of beneficial arthropods in greenhouse and open field: A review
}

\author{
Rita Papa, Giuseppe Manetto, Emanuele Cerruto, Sabina Failla \\ Department of Agricoltura, Alimentazione e Ambiente (Di3A), University of Catania, Italy
}

\begin{abstract}
In the last decades, political policies and collective consciousness focused on the importance of sustainable food and environmentally friendly approaches in agriculture. Distribution of beneficial organisms is a very important factor in integrated pest management, and mechanical release could improve application uniformity as well as reduce costs and working time. Several mechanisation experiences have been carried out through the years, however none of them has still found a massive application in common agricultural practices. This review paper analyses all the efforts made in this direction, by evaluating main strengths and weakness points of manually brought, tractor mounted, or aerial mechanical devices. In this way development opportunities can be identified, in a field that could achieve a substantial role in food production and agricultural activities while respecting the environment and human health.
\end{abstract}

\section{Introduction}

Environmentally friendly approaches such as integrated pest management and organic farming are widespread in the most recent agricultural practices. Sustainable food and agriculture are globally promoted by both the Food and Agricultural Organisation of the United Nations (FAO) and the World Health Organisation (WHO) to increase food security and public health (Mul et al., 2016). The application of biopesticides, defined as biological products or organisms, which are produced from a biological

Correspondence: Rita Papa, Department of Agricoltura, Alimentazione e Ambiente (Di3A), University of Catania, via S. Sofia 100, 95123 Catania, Italy.

Tel.: +39.0957147515 - Fax: +39.0957147605 .

E-mail: rita.papa@gmail.com

Key words: Aerial vehicles; biological control; mechanised release; portable devices; sustainable pest management; tractor mounted.

Received for publication: 5 September 2017.

Accepted for publication: 28 January 2018.

CCopyright R. Papa et al., 2018

Licensee PAGEPress, Italy

Journal of Agricultural Engineering 2018; XLIX:785

doi:10.4081/jae.2018.785

This article is distributed under the terms of the Creative Commons Attribution Noncommercial License (by-nc 4.0) which permits any noncommercial use, distribution, and reproduction in any medium, provided the original author(s) and source are credited. source outside the field (viruses, bacteria, fungi, predators, parasites and pheromones), fits the modern strategies of sustainable pest management. These agents utilise a variety of modes of action, hence their application presents some specificities. In particular, biopesticides are living organisms and great care is needed to maintain their viability (Gan-Mor and Matthews, 2003).

Although based on techniques gained through decades of experience, the application of predators (that capture and eat their preys) and parasitoids (that kill their host during their development within or on the body of the host) has not been significantly mechanised (Pezzi et al., 2015). Currently, natural enemies are manually released on infested crops, with a significant time loss (Lanzoni et al., 2007) and without achieving a uniform distribution of beneficials.

Despite the expected advantages of mechanical release in terms of reduced costs and working time and the possibility of improving application uniformity (Blandini et al., 2007a), the mechanical distribution of natural enemies such as predatory mites or other arthropods is limited. In general, the main limitation to mechanical release is that the beneficial organisms may be damaged by the machine parts during their handling and distribution; this is due to possible contact with mechanical elements and abrasion against carrier materials. Also, other technical and operational conditions restrict mechanical intervention. For example, the need to mix the beneficial organisms with carrier material for packing and shipping makes it difficult to handle and above all dose the mixtures; it is because the carrier material must be moist and it presents a high friction coefficient. Furthermore, the type of carrier material can differ in relation to the producer and beneficial arthropod species; so it is necessary to develop a machine that can be set and made suitable for different carrier materials and beneficial organisms (Pezzi et al., 2015).

A review of all the efforts made for mechanising this activity has been carried out since it could have a very important role in sustainable agriculture, whose importance is constantly increasing as statistical data and legislation on organic farming can demonstrate.

\section{Political and economic context}

\section{Regulations for sustainable agriculture}

Organic farming is regulated by a wide legislation, from European to regional scale. The aim is to guarantee the authenticity of methods applied, both for crops and livestock, and to control production, processing, labelling and marketing phases of organic products, as well as imports in the European Union from third countries.

European framework has its first legislative act for organic farming in Council Regulation (EEC) no. 2092/91, that was implemented on $1^{\text {st }}$ January 1993 in all member States (European 
Union, 1991). This Regulation established a harmonised framework for the production, labelling and inspection of agricultural products and foodstuffs, in order to increase consumer confidence in such products and ensure fair competition between producers (Berardini et al., 2006). In the following years many amending acts occurred, and currently rules for organic farming are defined by Council Regulation (EC) no. 834/2007 on organic production and labelling of organic products, that repealed the first legislation and entered into application on $1^{\text {st }}$ January 2009 (European Union, 2007). The Regulation in force guarantees more transparency and simplicity, clarity of aims and values, flexibility and possibility for adapting to local conditions, improvement of control system, reinforcement of the European Single Market, removal of barriers to organic products free trade in the European Union, and, for the first time in European history, it clearly matches organic farming with food quality, aiming at answering consumer needs. Moreover, it recognises organic farming having a double social role: satisfying consumer demand and supplying public goods that contribute to environment and biodiversity protection, animal welfare, and rural development (Agostino and Fonte, 2007).

Commission Regulation (EC) no. 889/2008, as amended by Council Regulation (EC) no. 1254/2008, lays down detailed rules for the implementation of Council Regulation (EC) no. 834/2007 with regard to organic production, labelling and control of organic products. Council Regulation (EC) no. 1235/2008 defines implementing rules about organic product imports from third countries (European Union, 2008a, 2008b, 2008c; National Rural Network 2007-2013, 2012). So much attention is continuously focused on sustainable agriculture that in 2014 a new consultation process had started, and it should lead to a reform in the European organic farming sector (AgroNotizie, 2015).

At the same time, the introduction of a direct support to organic farms happened at European level within agri-environment measures framework, and it greatly boosted the diffusion of organic method both in Europe and in Italy. In this way, however, organic sector did not have any balanced and sustainable economic development, with a too abundant supply compared to the real organic products demand. These problems let many national administrations and then European institutions looking for a better balance between supply and demand policies, through the development of integrated Action Plans for the whole organic industry and for the organic food market (Berardini et al., 2006). So, Action Plans have a strategic and global approach to organic industry, going beyond the simple support to the farms.

In wider terms, European Union establishes a Community framework for the sustainable use of pesticides, and two Directives regulate this aspect: Directive 2009/127/EC of the European Parliament and of the Council of 21 October 2009 amending Directive 2006/42/EC with regard to machinery for pesticide application; and Directive 2009/128/EC of the European Parliament and of the Council of 21 October 2009 establishing a framework for Community action to achieve the sustainable use of pesticides, by reducing the risks and impacts of pesticide use on human health and the environment, and promoting the use of integrated pest management and of alternative approaches or techniques such as non-chemical alternatives (European Union, 2009a, $2009 \mathrm{~b})$. The proposed measures concern in particular closer monitoring, increased training and information of users, as well as specific measures for the use of pesticides even for raising awareness about their risks.

Clearly, every Member State has kept up with the whole legislation evolution by adopting Community regulations or promulgating its own laws within the general framework.

\section{Organic agriculture in Europe}

The most recent available data, dating back to 2013, show that organic farming covers in the World an area corresponding to $1 \%$ of the total agriculture invested one, and this percentage is even higher in the European Union with a mean value of 5.7\%. Here, organic areas go on increasing, even if slower than in the previous time. Spain, Italy, France and Germany are the EU countries with the largest organic cultivated areas, even if the importance of organic farming is bigger in Austria, Sweden and Italy, with invested areas greater than $10 \%$ of the total agricultural one (Rete Rurale Nazionale 2007-2013, 2015).

As regards domestic sales value in Europe, the record is held by Germany, followed at a great distance by France, United Kingdom and Italy. However, Denmark has the greatest internal market development, because of both the highest average annual rate of change and the greatest incidence of consumption of organic food on the total food consumptions (8\%). Switzerland and Austria follow at a short distance, while in Italy this incidence equals only $2 \%$.

Regarding the value of the per capita consumption of organic products and foods, Italy has the lowest values although this indicator goes on growing year by year. On the other hand, in 2014 Italian organic exports represented $4 \%$ of the national food farming exports and this percentage continues growing, positioning Italy at the first place in the world for exports value, followed by Netherlands, Spain and United States. Italian exports are mainly directed to European countries, in particular Germany and France (Rete Rurale Nazionale 2007-2013, 2015).

\section{Statistical data on organic farms in Europe and Italy}

In order to understand the potential use of mechanical distribution systems of beneficials, data from important research institutes have been analysed to get more information about organic farming in Europe and in Italy. Moreover, considering that these systems have been primarily assessed on vegetable crops, attention has been focused on Italian open field and greenhouse horticulture. All data have been collected every five years since 2000 until the most recent year available for each information considered.

Table 1 (INEA, 2002, 2006, 2012; CREA, 2015) shows the spread of organic agriculture in European Union, in terms of both farms and invested areas. Looking at the aggregated data, a continuous expansion of organic agriculture can be noticed with mean farm sizes always growing, except for EU 27; this is because in Romania and Bulgaria number of farms increased more than proportionately to the areas, with a strong reduction in their mean farm sizes. No observation in time is available for EU 28 since Croatia entered the European Union just in 2013.

In many countries, especially in the last years, the growth of mean farm size is linked to a reduction in the number of organic farms. On the contrary, in Italy this phenomenon appeared from 2000 to 2010, while in the most recent years mean farm size went on growing together with the number of organic farms. The latter, however, is now still less than in 2000.

Italy has always had the biggest number of organic farms and organic invested areas, while its mean organic farm size has always been under the average European Union value. Variation trends are not homogeneous for all of the regions, but more than a half of the total number of organic farms is located in the Southern and Insular areas. Sicily has the greatest concentration of organic producers, equal to $18 \%$ of the total, followed by Calabria and Puglia. The three together represent more than $45 \%$ of national organic operators. 
Organic farming covers a wide range of crops (SINAB, 2000, $2005,2010,2015)$, with meadows and pastures, fodder and cereals representing over $60 \%$ of the total. In general, utilised agricultural area has grown through the years for almost all of the crops, especially for meadows and pastures and olive. In the mean time, fodder and industrial crops utilised areas have decreased. Vegetable crop areas have grown until 2010 and then they did not have substantial variation; at the moment they represent $2 \%$ of the total organic invested areas.

Since mechanical experiences of arthropods distribution have been mainly carried out in horticultural crops, data related to vegetable crops invested areas and production in each Italian region have been collected by ISTAT database (ISTAT, 2000, 2005, 2010, 2015).

Open field vegetable farming shows a variable trend during the years, with invested areas often decreasing in time until now. Only a few regions (Emilia Romagna, Lombardia, Friuli Venezia Giulia) had a little recovery in the last years. Consequently, productions are fluctuating, too. Puglia $(73,713$ ha) is the most intensively cultivated region, just followed by Sicily (52,939 ha).

Greenhouse farming is characterised by smaller areas but greater mean yields $\left(46 \mathrm{t} \mathrm{ha}^{-1}\right)$ than open field farming $\left(30 \mathrm{t} \mathrm{ha}^{-1}\right)$. Southern regions and Islands represent about $60 \%$ of the national invested area and $55 \%$ of the total production. Even in greenhouse, vegetable farming area and production trends variously fluctuated over the years. Through a comparison between organic vegetable crops invested area and the total vegetable crops invested one (in open field and greenhouse), it comes out that the percentage of organic farming has significantly grown up in the years. Until 2005 it was about $3.6 \%$ while later until now it is equal to $7 \%$.

Table 1. Number of organic farms and organic invested areas in European Union.

\begin{tabular}{|c|c|c|c|c|c|c|c|c|c|c|c|c|c|}
\hline \multirow[t]{2}{*}{ Country } & \multicolumn{3}{|c|}{2000} & \multicolumn{3}{|c|}{2005} & \multicolumn{3}{|c|}{2010} & \multicolumn{3}{|c|}{2013} & \\
\hline & Farms & $\begin{array}{c}\text { Areas } \\
\text { (ha) }\end{array}$ & $\begin{array}{l}\text { Mean } \\
\text { farm } \\
\text { size } \\
\text { (ha) }\end{array}$ & Farms & $\begin{array}{c}\text { Areas } \\
\text { (ha) }\end{array}$ & $\begin{array}{c}\text { Mean } \\
\text { farm } \\
\text { size } \\
\text { (ha) }\end{array}$ & Farms & $\begin{array}{c}\text { Areas } \\
\text { (ha) }\end{array}$ & $\begin{array}{l}\text { Mean } \\
\text { farm } \\
\text { size } \\
\text { (ha) }\end{array}$ & $\begin{array}{c}\text { Farms } \\
\text { (ha) }\end{array}$ & $\begin{array}{c}\text { Areas } \\
\text { (ha) }\end{array}$ & $\begin{array}{c}\text { Mean } \\
\text { farm } \\
\text { size } \\
\text { (ha) }\end{array}$ & \\
\hline Belgium & 628 & 20,263 & 32 & 693 & 22,996 & 33 & 1108 & 49,005 & 44 & 1487 & 62,529 & 42 & \\
\hline Denmark & 3466 & 165,258 & 48 & 2892 & 145,636 & 50 & 2677 & 162,903 & 61 & 2589 & 169,298 & 65 & \\
\hline Germany & 12,732 & 546,023 & 43 & 17,020 & 807,406 & 47 & 21,942 & 990,702 & 45 & 23,271 & $1,060,669$ & 46 & \\
\hline Greece & 5270 & 24,800 & 5 & 14,614 & 288,255 & 20 & 21,274 & 309,823 & 15 & 23,433 & 383,606 & 16 & * \\
\hline Spain & 13,424 & 380,838 & 28 & 15,693 & 807,569 & 51 & 27,877 & $1,456,672$ & 52 & 30,502 & $1,610,129$ & 53 & \\
\hline France & 9283 & 371,000 & 40 & 11,402 & 560,838 & 49 & 20,604 & 845,442 & 41 & 25,467 & $1,060,756$ & 42 & \\
\hline Ireland & 1014 & 32,355 & 32 & 978 & 35,266 & 36 & 1366 & 47,864 & 35 & 1263 & 52,793 & 42 & * \\
\hline Italy & 51,120 & $1,040,377$ & 20 & 44,733 & $1,067,102$ & 24 & 41,807 & $1,113,742$ & 27 & 45,969 & $1,317,177$ & 29 & \\
\hline Luxembourg & 51 & 1030 & 20 & 72 & 3243 & 45 & 96 & 3720 & 39 & 212 & 4448 & 21 & \\
\hline Holland & 1391 & 27,820 & 20 & 1377 & 48,765 & 35 & 1462 & 46,233 & 32 & 1646 & 49,394 & 30 & $*$ \\
\hline Austria & 19,031 & 271,950 & 14 & 20,310 & 360,972 & 18 & 22,132 & 543,605 & 25 & 21,810 & 526,689 & 24 & \\
\hline Portugal & 763 & 50,002 & 66 & 1577 & 233,458 & 148 & 2434 & 201,054 & 83 & 3308 & 271,532 & 82 & $*$ \\
\hline Finland & 5225 & 147,423 & 28 & 4296 & 147,587 & 34 & 4022 & 169,168 & 42 & 4284 & 206,170 & 48 & \\
\hline Sweden & 3329 & 171,682 & 52 & 2951 & 200,010 & 68 & 5208 & 438,693 & 84 & 5584 & 500,996 & 90 & \\
\hline United Kingdom & 3563 & 527,323 & 148 & 4285 & 619,852 & 145 & 4949 & 699,638 & 141 & 3918 & 567,751 & 145 & \\
\hline Total EU 15 & 130,290 & $3,778,144$ & 29 & 142,893 & $5,348,955$ & 37 & 178,958 & $7,078,264$ & 40 & 194,743 & $7,843,937$ & 40 & \\
\hline Cyprus & - & - & - & 305 & 1698 & 6 & 732 & 3575 & 5 & 719 & 3923 & 5 & * \\
\hline Czech Republic & - & - & - & 829 & 254,982 & 308 & 3517 & 448,202 & 127 & 3910 & 474,231 & 121 & \\
\hline Estonia & - & - & - & 1013 & 59,862 & 59 & 1356 & 112,972 & 83 & 1553 & 151,256 & 97 & \\
\hline Hungary & - & - & - & 1553 & 123,569 & 80 & 1617 & 127,605 & 79 & 1673 & 140,292 & 84 & \\
\hline Latvia & - & - & - & 2873 & 118,612 & 41 & 3593 & 166,320 & 46 & 3473 & 200,433 & 58 & \\
\hline Lithuania & - & - & - & 1811 & 69,430 & 38 & 2652 & 143,644 & 54 & 2555 & 166,330 & 65 & \\
\hline Malta & - & - & - & 6 & 14 & 2 & 11 & 24 & 2 & 12 & 37 & 3 & $*$ \\
\hline Poland & - & - & - & 7183 & 167,740 & 23 & 20,578 & 521,970 & 25 & 25,944 & 661,956 & 26 & $*$ \\
\hline Slovak Republic & - & - & - & 196 & 92,191 & 470 & 363 & 174,471 & 481 & 365 & 166,700 & 457 & $*$ \\
\hline Slovenia & - & - & - & 1718 & 23,499 & 14 & 2218 & 30,696 & 14 & 3,049 & 38,665 & 13 & \\
\hline Total EU 25 & - & - & - & 160,380 & $6,260,552$ & 39 & 215,595 & $8,807,743$ & 41 & 237,996 & $9,847,760$ & 41 & \\
\hline Bulgaria & - & - & - & - & - & - & 709 & 25,648 & 36 & 3854 & 56,287 & 15 & \\
\hline Romania & - & - & - & - & - & - & 2986 & 182,706 & 61 & 15,315 & 288,261 & 19 & * \\
\hline Total EU 27 & - & - & - & - & - & - & 219,290 & $9,016,097$ & 41 & 257,165 & $10,192,308$ & 40 & \\
\hline Croatia & - & - & - & - & - & - & - & - & - & 1608 & 40,641 & 25 & \\
\hline Total EU 28 & - & - & - & - & - & - & - & - & - & 258,773 & $10,232,949$ & 40 & \\
\hline
\end{tabular}

Source: INEA $(2002,2006,2012)$ and CREA (2015) (L'agricoltura italiana conta); *2012. 


\section{Application of beneficial organisms in agriculture}

Since the nineteenth century agriculture has greatly developed, with productivity going to the detriment of durability and sustainability. Sustainable needs gradually increased, and the twenty-first century is characterised by technologies and innovations leading to integrated crop protection; even European Union policy promotes integrated pest management (IPM) systems rather than conventional ones. IPM strategies include plant resistance, reduced effects on non-target organisms, and on the environment (Lamichhane, 2017), and the use of biological control of pest. The latter can be realised through three main techniques (Bale et al., 2008; Wright, 2014): i) classical or inoculative biological control, mainly used against exotic pests that have become established in new countries or regions of the world, by introducing natural enemies from the place of origin of the pest; ii) augmentative biological control, with the repeated introduction or release of natural enemies into a cropping system; it can be inundative or inoculative; iii) conservation biological control, when indigenous or naturalised natural enemies of pests are conserved within the borders of crop fields.

\section{Experiments of mechanical distribution of arthropods in sustainable agriculture}

In the last forty years, different researches have been carried out to evaluate some devices for releasing natural enemies on extensive or greenhouse crops. They developed new machines or they tried to adapt existing instruments. All of these efforts can be classified by the distribution approach adopted, since there are devices manually brought, tractor mounted or for aerial release. Known experiences have been summarised in Table 2.

\section{Manually brought machines}

In the nineties, the feasibility of distributing an aqueous suspension of Chrysoperla rufilabris eggs and Trichogramma pretiosum from parasitised eggs of Ephestia kuhniella through a spraying machine was investigated. The objectives were to evaluate: effects of long water exposure on eggs opening; concentration uniformity; opening percentage after releasing in a liquid medium through a wide-orifice fan nozzle. Each egg was placed in one of the 54 singulating cells of a plate. The latter was covered with a nylon mesh at the bottom, and it was located between a clear acrylic top plate and a mesh support plate, that prevented larvae moving away (Gardner and Giles, 1996).

Applying natural enemies through a liquid way showed some advantages: spray technology is quite familiar to farming sector; equipment is already available or easily acquirable; application is simple; uniformity is sound; and calibration procedures are well developed (Gardner and Giles, 1997).

Another research related to distributing beneficials (C. rufilabris eggs) through spraying was that carried out by Wunderlich and Giles (1999) for field evaluation of mechanical distributor and performances of the released eggs. The effects of conditioning, transport and releasing techniques on the opening of the distributed eggs were assessed. In order to distinguish environmental effects on opening and productiveness from any other effect of mechanical distribution, the manual one was investigated too. Foliage adhesion and real eggs opening were assessed, since the number of active larvae depended on both these parameters; mechanical distribution seemed not to influence them. As regards conditioning, incubation leads to a stage very close to opening, and it showed

Table 2. Synoptic table of mechanisation experiences in distributing natural enemies.

\begin{tabular}{|c|c|c|c|c|c|}
\hline $\begin{array}{l}\text { Distribution } \\
\text { approach }\end{array}$ & Device & Beneficial & Authors & Year & $\begin{array}{l}\text { Work capacity/ } \\
\text { device } \\
\text { effectiveness }\end{array}$ \\
\hline \multirow[t]{6}{*}{ Manually brought } & Spraying machine & $\begin{array}{l}\text { Chrysoperla rufilabris, } \\
\text { Trichogramma pretiosum }\end{array}$ & Gardner, Giles & 1996 & Uniformity \\
\hline & Spraying machine & Chrysoperla rufilabris & Giles, Wunderlich, & 1999 & Greater eggs opening percentage \\
\hline & $\begin{array}{l}\text { Blower, with or without } \\
\text { metering device }\end{array}$ & $\begin{array}{l}\text { Phytoseiulus persimilis, } \\
\text { Amblyseius cucumeris }\end{array}$ & $\begin{array}{l}\text { Margolies, Nechols, } \\
\text { Opit, Williams }\end{array}$ & 2005 & n.a. \\
\hline & Knapsack sprayer & $\begin{array}{l}\text { Phytoseiulus persimilis, } \\
\text { Orius laevigatus }\end{array}$ & $\begin{array}{l}\text { Baraldi, Caprara, } \\
\text { Martelli, Pezzi, } \\
\text { Rondelli }\end{array}$ & 2002,2007 & $\begin{array}{l}\text { Work capacity } 6 \text { - } 10 \text { times } \\
\text { manual distribution }\end{array}$ \\
\hline & Blower & $\begin{array}{l}\text { Phytoseiulus persimilis, } \\
\text { Amblyseius swirskii }\end{array}$ & $\begin{array}{l}\text { Maini, Martelli, } \\
\text { Lanzoni, Pezzi }\end{array}$ & 2015,2017 & $0.0452-0.0943$ ha h$^{-1}$ \\
\hline & $\begin{array}{l}\text { Doser hopper on a } \\
\text { rotating distributor disc }\end{array}$ & $\begin{array}{l}\text { Phytoseiulus persimilis, } \\
\text { Orius laevigatus }\end{array}$ & $\begin{array}{l}\text { Blandini, Emma, Failla, } \\
\text { Manetto, Papa, Restuccia, } \\
\text { Siscaro, Tropea Garzia, } \\
\text { Zappalà }\end{array}$ & $\begin{array}{l}2006,2007 \\
2008,2010 \\
2011,2012\end{array}$ & $0.11-0.72$ ha h$^{-1}$ \\
\hline \multirow[t]{3}{*}{ Tractor mounted } & $\begin{array}{l}\text { Rotating circular } \\
\text { and flat container }\end{array}$ & Phytoseiulus persimilis & Gardner, Giles, Studer & 1995 & $\begin{array}{l}\text { Work capacity double } \\
\text { than manual distribution }\end{array}$ \\
\hline & $\begin{array}{l}\text { Cylindrical reservoir } \\
\text { with rotating metering disc }\end{array}$ & $\begin{array}{l}\text { Phytoseiulus persimilis, } \\
\text { Chrysoperla rufilabris }\end{array}$ & Gardner, Giles, Studer & 1995 & n.a. \\
\hline & $\begin{array}{l}\text { Doser hopper on a rotating } \\
\text { distributor disc }\end{array}$ & $\begin{array}{l}\text { Phytoseiulus persimilis, } \\
\text { Orius laevigatus }\end{array}$ & $\begin{array}{l}\text { Emma, Failla, Manetto, } \\
\text { Restuccia }\end{array}$ & 2010,2012 & $\begin{array}{l}1.0 \text { ha }^{-1}(\text { P. persimilis }) \\
0.6 \text { ha h }^{-1}(\text { O. laevigatus })\end{array}$ \\
\hline \multirow[t]{5}{*}{ Aerial } & $\begin{array}{l}\text { Aircraft with distribution } \\
\text { system in an electric cooler }\end{array}$ & Phytoseiulus persimilis & $\begin{array}{l}\text { Bouse, Gilstrap, } \\
\text { Morrison, Pickett }\end{array}$ & 1987 & 204 ha h$^{-1}$ \\
\hline & $\begin{array}{l}\text { Three-axle motor ultralight } \\
\text { with two cylindrical tanks }\end{array}$ & Trichogramma maidis & Gattavecchia, Libè, Maini & 1988 & 25 ha h$^{-1}$ \\
\hline & Airborne insect release system & Amblyseius idaeus & Drukker, Herren, Yaninek & 1993 & n.a. \\
\hline & $\begin{array}{l}\text { Quadcopter drone with } \\
\text { automatic dispenser }\end{array}$ & Trichogramma brassicae & Comal, Koppert & 2014 & n.a. \\
\hline & Unmanned Aerial Vehicle & Trichogramma pretiosum & das Cruzes, Rangel & 2016 & n.a. \\
\hline
\end{tabular}


better results than refrigeration. In conclusion, the system proved to be quite simple and cheap, it did not cause auxiliary insects death, and it determined eggs opening percentage greater than manual distribution (Wunderlich and Giles, 1999).

Some years later, mechanical portable devices were developed for releasing beneficials in greenhouses through an airstream generated by a small fan. In the United States, a research was carried out for distributing Phytoseiulus persimilis and Amblyseius cucumeris predatory mites through two mechanical blowers, provided or not with a metering device to control the flow of material (Opit et al., 2005). Objectives were determining horizontal distribution of natural enemies and comparing survival rates of mites dispensed by the two mechanical blowers and the manual-sprinkling method, as well as time needed and estimated total costs to growers. The metering device allowed an amount of carrier material (vermiculite or bran, in which the predatory mites are shipped) to be metered into a tube; the mixture was then blown onto canopies. Each dose could range between 0.15 and $2.50 \mathrm{~mL}$ of material.

In the device without metering system, the flow of material was regulated just by tilting the tube through which the mixture carrying the natural enemies was blown onto canopies. The percentage of alive $P$. persimilis mites was low when distributed with the metering device, average without it, and high when manually released. With $A$. cucumeris, a low percentage of alive samples distributed with the metering device was assessed, while it was higher without it and with manual releasing, showing the latter two methods similar values. Mean time needed for distributing both predatory mites gradually increased by passing from system without metering device to manual dispensing. In the end, as regards costs, mechanical blower without metering system amounted to half that of manual release method for $P$. persimilis. Therefore, the lack of the measuring device was positively considered, since it allowed a faster distribution and a lower mite's death rate (Opit et al., 2005).

In Italy, at Bologna University, the former Department of Agricultural Economics and Engineering (DEIAgra), now Department of Agricultural and Food Sciences, developed a prototype for distributing Phytoseiulus persimilis, and it was tested on greenhouse strawberry crops. The device was electrically driven and it measured out the product and let it fall in an air flow. Distribution was carried out through interchangeable outlets, for sprinkling product on the whole area or on two lines. Results demonstrated phytoseiids mechanical distribution being an efficient way in contrasting phytophagous mites, without damaging natural enemies (Pezzi et al., 2002), and assuring a bigger sprinkling productivity than manual activity, with treated areas 6-10 times larger in the time unit (Pezzi et al., 2007).

This device was then tested as an accessory for commercial spraying machines, in particular a multi-purpose knapsack sprayer, with an internal combustion engine, for pneumatic distribution of liquid or powdered products. Prototype was applied to the sprayer end part, for being faster and easier its connection and disconnection. Distribution system extracted arthropods and carrier material through a tip entering with alternate motion the overturned container (Figure 1A and B).

Tip frequency and stroke were controlled by an electromagnet and determined the amount of pouring material that, falling down in the diffuser, was carried and distributed by the fan generated air flow. This configuration was tested both in laboratory and in greenhouse. Lab trials were related to: measuring air flow generated, in order to identify better conditions for distributing arthropods in greenhouse; verifying system functionality in flow rate regulation and sprinkling characteristics; checking distributed arthropods vitality to assess possible damages due to throwing system. With regard to air flow, better results were obtained with engine lower regimes, since exit air speed $\left(23.5 \mathrm{~m} \mathrm{~s}^{-1}\right)$ allowed material reaching 9-10 m distances, with a quite regular and wide flux. System functionality check was set on phytoseiid $P$. persimilis distribution, and its carrier material (humid vermiculite at $35-40 \%$ ) was used in payload regulation and distribution characteristics checks, since there was a good correspondence between its deposits and the phytoseiid's ones. Then, distribution and vitality of Orius laevigatus were checked too. It was sprinkled in its larval phenological stage, to allow mechanical distribution and to increase its predatory capacity. Carrier material was buckwheat husk. Phytoseiulus vitality was similar in manual and mechanical sprinkling, while Orius survival in mechanical distribution was $30 \%$ lower than in manual one. In greenhouse trials (Figure 1C), biological checks were done in experimental conditions on aubergine and cucumber for P. persimilis and $O$. laevigatus respectively, and in real conditions only on aubergine. For its assembly characteristics, the prototype turned out an effective accessory for the distribution machine used. Regulation system could guarantee dosage adequate to organic protection. Mechanical sprinkling with pneumatic system allowed to control and adapt spatial distribution, even in scarce accessibility condition such as greenhouse farming. Both in experimental and in real conditions, mechanical distribution of $P$. persimilis and $O$. laevigatus determined the same protection rate than the manual sprinkling. The greatest difference between the two distribution ways was working time, really reduced with mechanical throwing. This was interesting for the control of production costs, a greater intervention promptness, and for reducing the exposure of the operators to the uncomfortable and tiring working conditions typical of greenhouses, with very high temperature and humidity values (Caprara et al., 2007).

Another research was carried out to evaluate a new model of the earlier prototype (Pezzi et al., 2002) for the air-assisted distribution of predatory mites $P$. persimilis and Amblyseius swirskii, in both separate and combined releases. The specific objectives were to: describe the air-flow diagrams of distribution; determine the pattern of carrier material distribution; compare the survival and reproduction of the predatory mites after mechanical and manual distribution. The carrier material used in the commercial packag-

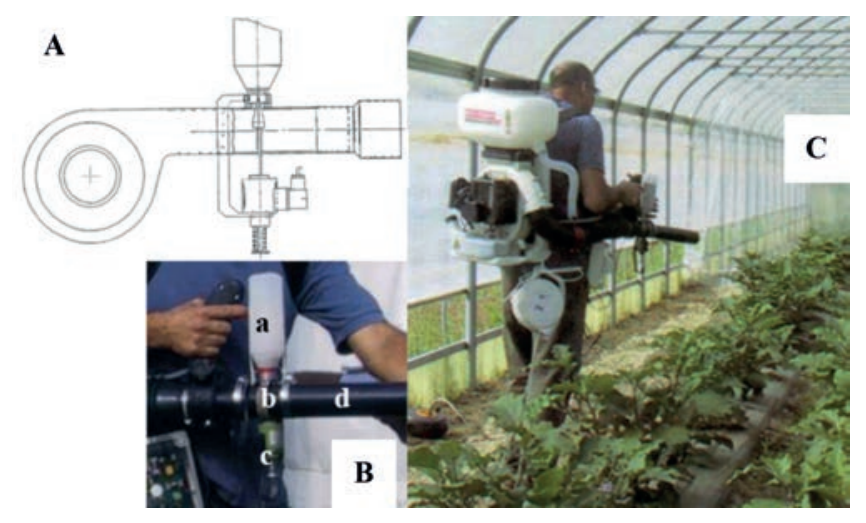

Figure 1. A) Scheme of biological material extraction and distribution system; B) prototype applied to a sprayer diffuser: a) bottle containing beneficial organisms; b) extraction system; c) electromagnet; d) air diffuser; C) phytoseiid sprinkling in greenhouse (Caprara et al., 2007). 
ing was vermiculite for $P$. persimilis and vermiculite mixed with a small percentage of bran for A. swirskii. The prototype provided satisfactory results from the operational point of view. The practicality of the device integrated with a system for dose-metering and extracting the product directly from the bottle in which it was marketed resulted adequate, despite the unfavourable physical characteristics of the carrier materials in which the arthropods were dispersed. The distribution pattern generated by the blower running at medium air speed guaranteed a range $(1.5-3 \mathrm{~m})$ of uniform horizontal distribution of predatory mites that can be considered suitable for the confined spaces typical of greenhouses. This broadcast width gave adequate cover by alternately distributing in two directions without the need for additional aisles that would be required for manual sprinkling. The tests demonstrated that the use of the prototype did not reduce the viability or reproductive capacity of either $P$. persimilis or $A$. swirskii with respect to manual sprinkling. The extraction and dose-metering system fitted to the blower did not produce adverse effects on the two species of predatory mites studied. Furthermore, $P$. persimilis survival and fecundity did not decrease when the blower was run at a high air speed. If inoculation biological control was intended, reproduction of dispersed predators represented a key element.

The results of this study showed that a blower could be effectively used in inoculation biological control strategies. Moreover, also in the case of inundation biological control, the inundative effect could be expected to be followed by some residual inoculative effect, since some reproduction by the released individuals could reasonably be expected. Another important aspect emerging from the study was that, since there was no additional mortality when predators were delivered with the blower, the optimal release rate, found to be effective with manual sprinkling, did not have to be modified. The mechanical blower showed the advantage of being less time-consuming and labour-intensive than manual sprinkling (Pezzi et al., 2015).

After laboratory tests, the device was used to control eggplant pests in a greenhouse. The application of $P$. persimilis and $A$. swirskii to T. urticae and F. occidentalis control in the protected crop was evaluated to compare mechanical and manual distribution using different application strategies and predatory mite formulations: hand-sprinkling, separate mechanical release, combined mechanical release and paper sachets for $A$. swirskii release along with mechanical $P$. persimilis release. Mechanical release treatments ensured a uniform horizontal distribution of predatory mites and required less working time than hand sprinkling $(0.0158$ ha $\mathrm{h}^{-1}$ ): $0.0595 \mathrm{ha}^{-1}$ for the separate mechanical release, 0.0943 ha $\mathrm{h}^{-1}$ for the combined one, and $0.0452 \mathrm{ha}^{-1}$ for paper sachets application (Lanzoni et al., 2017).

Another Italian academic institution spent efforts on mechanical distribution of natural enemies. Almost ten years ago, the former Department of Agricultural Engineering (DIA), now Department of Agricoltura, Alimentazione e Ambiente (Di3A), of Catania University developed a prototype for mechanical distribution of Phytoseiulus persimilis and Orius laevigatus, that was patented both in Italy (Blandini et al., 2007b) and in USA (Blandini et al., 2007c). This prototype used operating principles different from the ones of other Italian or foreign devices realised for the same purpose, since it was based on the centrifugal force. After several laboratory and field tests, these principles proved to be suitable for mechanical releasing natural enemies; moreover, the use of electrical engines ensured prototype manageability and reduced costs and environmental impact (Blandini et al., 2006).

At first, a laboratory prototype was realised. The system was equipped with an aluminium hopper of $1 \mathrm{dm}^{3}$ capacity with inside, at its vertical axis, a helicoidal doser for regulating the amount of product to be released. The hopper was placed above a distributing device, that was a finned rotating disc electrically activated. Many lab tests were carried out together with the former Department of Phytosanitary Sciences and Technologies (DISTEF), now Di3A, of Catania University, and it was observed that: beneficials were not damaged by the dispenser nor by the distributing disc; desired quantities could be scattered; natural enemies and carrier material were able to reach the target; the prototype was easy to construct and cheap, with a null environmental impact.

After these trials, a field prototype that could be carried by the operator in the inter-rows (Figure 2A) was designed and constructed. It was equipped with a conical polypropylene hopper of $2 \mathrm{dm}^{3}$ capacity, able to treat about $1000 \mathrm{~m}^{2}$ greenhouse without intermediate supplying. The amount to be sprinkled could be regulated by modifying the doser rotation speed, the diameter of exit hole, or the diameter of the doser. Moreover, the hopper was set along a support loop that could rotate around an axis coaxial to the one of distributor disc. In this way, the advance angle towards frame symmetry axis that threw product and its point of release on disc could be regulated. Instead, if rotation speed of distributing disc or radial hopper position were modified, the prototype range of action could be defined. Both distributor disc and hopper support were anchored to a frame that kept constant the distance between them.

For experimental reasons, the prototype was mounted on a support frame with wheels (Figure 2B). On the frame, a hexagonal vertical mast allowed the prototype to be positioned at the desired height, in order to adapt distribution to crop and its vegetative stage. With the prototype a lot of trials were carried out in lab, prior to the field ones, in order to characterise device functional parameters and to improve distributor and its regulation for greenhouse applications. In particular, for each carrier material and beneficial used (humid vermiculite with P. persimilis, or buckwheat husk and

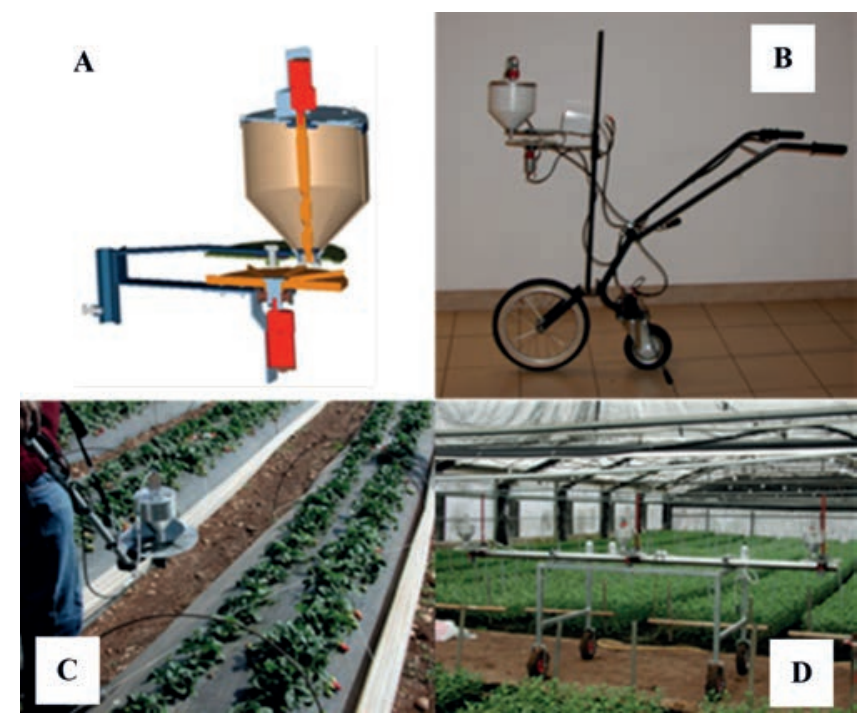

Figure 2. A) Three-dimensional prototype section; B) the prototype installed on the experimental frame (Blandini et al., 2006); C) the prototype carried by an operator (Emma et al., 2010); D) three prototypes on a wheel frame. [Panel D reproduced with permission from: Zappalà, L., Manetto, G., Tropea Garzia, G., Emma, G. and Failla, S. (2012). Mechanical distribution of Phytoseiulus persimilis on Chrysanthemum. Acta Hortic. 952; 793-800. DOI: https://doi.org/10.17660/ActaHortic.2012.952. 100] 
humid vermiculite with $O$. laevigatus), it was observed: throw direction; amount of product distributed; throw distance; effects on natural enemies; distribution uniformity. Then, the prototype was used in sweet pepper greenhouse, comparing for both natural enemies manual and mechanical sprinkling (Blandini et al., 2007a, 2008a; Failla et al., 2012; Tropea Garzia et al., 2012).

Later, a new version of this prototype, that could directly be carried by the worker by means of a bar with a shoulder strap and lateral handle, was realised. It had the same operating principle, but differed from the previous version in terms of material (aluminium) and size (the hopper was about $1.5 \mathrm{dm}^{3}$, the finned disc had a diameter of $300 \mathrm{~mm}$ ), to improve manoeuvrability and range of action so to reduce the working time (Blandini et al., 2008b; 2008c; Blandini et al., 2010).

An application of this new version of prototype was used for experimental trials in strawberry open field (Figure 2C) (Emma et al., 2010; Failla et al., 2012). Some other trials were carried out in a chrysanthemum greenhouse (Failla et al., 2012; Tropea Garzia et al., 2012; Zappalà et al., 2012) for releasing $P$. persimilis and $O$. laevigatus, with three prototypes applied to a carrying bar on the top of a four-wheel frame manually driven (Figure 2D). Frame wheelbase could vary between 0.85 and $1.50 \mathrm{~m}$ in function of the crop lay-out, the carrying bar was disposed transversally to the forward direction, and the distance separating each prototype could be regulated in accordance with the layout of the crop in the field. The prototypes were connected electrically to one another in parallel, powered by a single battery and activated by a single switch (Zappalà et al., 2012). The three prototypes could be conveniently adapted for being applied to motorised bars at greenhouse top (Blandini et al., 2011).

In all experimental trials carried out with the device, it was found a greater uniformity of distribution, a reduction of release time and ease of application with respect to the manual distribution. In most of the plots with mechanical distribution, the predators were regularly recovered reducing the percentage of leaves infested and their density, so controlling pests sooner than in the manually released ones (Tropea Garzia et al., 2012). With the first field version used on sweet pepper the average time to turn the machine was relatively high because of the scarce manoeuvrability (Failla et al., 2012). Work capacity was on average 0.43 ha $\mathrm{h}^{-1}$, ranging from 0.11 to $0.72 \mathrm{ha} \mathrm{h}^{-1}$ depending on beneficial and dose distributed (Blandini et al., 2011).

Many laboratory trials were carried out and results showed the last version of the prototype to be suitable for organic pest management, for dosage, distribution mechanism, and low or null impact on distributed natural enemies (Blandini et al., 2008c). With the new version used on strawberry crops, the manoeuvrability was much improved and consequently better and more constant results were obtained in terms of both work capacity and uniformity of distribution. The work capacity of the mechanical configuration tested demonstrated advantages compared to manual distribution (Emma et al., 2010). Also the version used on chrysanthemum allowed to obtain a good uniformity of distribution with rewarding work capacity (Failla et al., 2012). It achieved actual work capacities of about 0.18 and 0.24 ha $\mathrm{h}^{-1}$, compared with a 0.14 ha $\mathrm{h}^{-1}$ work capacity performed in manual distribution. Product flows were quite uniform for both arthropods (Zappalà et al., 2012). Thanks to the better results in terms of work capacity, costs would be contained when compared with those of manual distribution practiced so far (Failla et al., 2012).

\section{Tractor mounted machines}

In California, a machine for throwing Phytoseiulus persimilis predatory mite on strawberry crops was realised by Giles et al. (1995). The objectives were: to design a system able to release natural enemies and carrier material as commercially produced, without greatly damaging organisms and with a precise control of the amount released; to quantify precision of the obtainable amount and distribution uniformity. The throwing system was set on the tractor toolbar and it was activated by the machine electric system; it could release from 25,000 to 75,000 mites per hectare.

The first project was a circular flat container, rotating around its central axis (Figure 3A). Its rotation, however, caused a high death rate $(75-90 \%)$ of mites distributed. The project was then modified and a device (Figure 3B) made of a cylindrical reservoir with a passage port directed to a rotating metering disc was developed. The disc had 16 cells and it was electrically driven; its rotation let the mixture going out the release port. An air breath made each cell empty before leaving release area.

Reservoir and discs were transparent for visual examination (Figure 3C). This kind of distributor allowed to check volume and frequency of each emission, through capacity and number of cells in the rotating disc and its rotation speed. The prototype was evaluated for its physical and biological performances. For field assessment, it was fit on tractor toolbar (Figure 3D). On the bar, a compressor was fit too, for producing the air needed to empty metering disc cells. Results showed a uniform mite release and a work productivity almost doubling manual distribution (Giles et al., 1995).

Again in California, a machine for distributing Chrysoperla rufilabris eggs was assessed, and it showed a good distribution uniformity and a scarce damage rate. The eggs were mixed with vermiculite and distributed through the device designed by Giles et al. (1995) for the dispersal of predatory mites (Figure 3B). Eggs vitality was evaluated by observing larvae appeared after a fiveday incubation period. Plates already described, with 60 cells

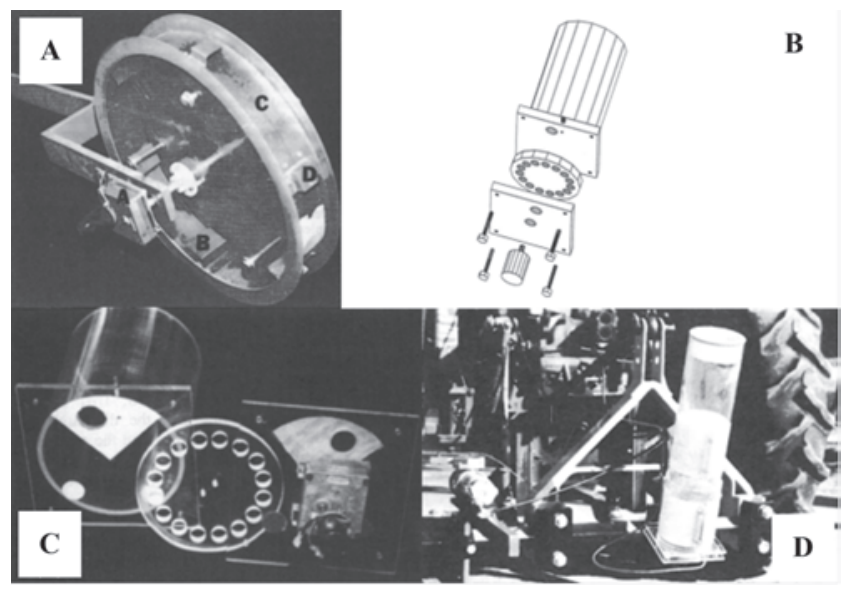

Figure 3. A) Rotating container with transparent sides: a) gearmotor; b) internal Z-brackets; c) outer ring; d) external brackets; B) mechanical distributor; C) distributor components; D) distributor fit on the tractor tool bar. [Reproduced from: "Mechanical release of predacious mites for biological pest control in strawberries" by D. K. Giles, J. Gardner, and H.E. Studer. Transactions of the ASAE 38(5), 1289-1296. Copyright 1995 American Society of Agricultural Engineers. Used with permission.] 
rather than 54, were used for checking eggs vitality (Gardner and Giles, 1996).

An application of the last version of the already described prototype of University of Catania was mounted on a carrying bar connected to three linkage points to a tractor (Figure 4), and it was assessed in strawberry open field (Emma et al., 2010; Failla et al., 2012). In this case, three prototypes were attached to three support rods and electrically connected each other in parallel. The height of the prototypes could be regulated and the best distance separating them could be chosen according to the arrangement of the crop in the field. Work capacity was $1.0 \mathrm{ha}^{-1}$ for $P$. persimilis and 0.6 ha $\mathrm{h}^{-1}$ when distributing $O$. laevigatus; these unlike results were due to different flow rates and mean forward speed for the two arthropods released (Blandini et al., 2011).

\section{Devices for aerial release of natural enemies}

In 1985, a little aircraft was used to release Phytoseiulus persimilis on corn fields in Texas, whose tablelands were infested by Oligonychus pratensis and Tetranichus urticae mites (Pickett et al., 1987). Distribution system was located in an electric cooler for reducing predator movements and preventing their excessive loss during scattering. The aim was to test the system ability in uniform distribution of phytoseiids. Mites were released in three study fields, with corn grown without pesticides or with an amount of them really lower than usual in that area. Predators were released once, on the basis of adult female density of mites infesting corn. A quantity of 7410 predators per hectare mixed with corn flour was distributed, this number corresponding to what could be bought with the same amount needed for a pesticide treatment. Throwing had a $204 \mathrm{ha} \mathrm{h}^{-1}$ covering index, a speed of $53.75 \mathrm{~m} \mathrm{~s}^{-1}$ and an interval of $10.7 \mathrm{~m}$; predators were released $15.2 \mathrm{~m}$ above the crop and the amount of material distributed by the aircraft was $325 \mathrm{~mL} \mathrm{~min}^{-1}$, corresponding to a dose of $96 \mathrm{~mL} \mathrm{ha}^{-1}$. Two sampling designs were used: a direct count method (e.g. number of mites per plant) aimed to determine distribution in time and effect of the predators released, and another design aimed to estimate the distribution of mites between plants in the treated area, and just their presence or absence was investigated rather than the number of predators per plant. The study showed that this system was able to uniformly distribute predatory mites, so that they could effectively control phytophagous (Pickett et al., 1987).

Another aircraft was tested in Italy for distributing hymenopterous parasitoids Trichogramma maidis over wide corn fields, in order to limit pyralis (Ostrinia nubilalis) attacks (Maini et al., 1988; Maini and Burgio, 2000). A three-axle motor ultralight was used (Figure 5), equipped with two cylindrical transparent tanks for throwing cardboard capsules. Each one of these contained about 500 Ephestia kuehniella pantry moth eggs parasitised by $T$. maidis. The tanks had an electric distribution system with battery supply, and the pilot could regulate its speed or stop it. The aircraft flew at a speed of $13.3 \mathrm{~m} \mathrm{~s}^{-1}$ and distributed 1-1.5 capsules per second (200 or 300 capsules per hectare for each throwing). After the treatment, the percentage of $O$. nubilalis parasitised was high and $T$. maidis kept its reproductive capacity in field. Moreover, the aircraft showed a high work capability (about 25 ha h $^{-1}$ ).

A similar research was carried out in Africa for the aerial release of phytoseiid Amblyseius idaeus, predator of the cassava green mite Mononychellus tanajoa (Drukker et al., 1993). An aircraft provided with twin turboprop was used. It had a $2100 \mathrm{~km}$ flight range, a cruising speed of $80-90 \mathrm{~m} \mathrm{~s}^{-1}$, and an adapted airborne insect release system (AIRS), since it was formerly designed for throwing the parasitoid of cassava cochineal. AIRS (Figure 6A) was made of: a metal frame bearing release cassettes with natural enemies containers; a pressurised ejection system; a tubular distribution system, made of a main release tube and a minor one, both with a part above the fuselage. The two tubes were connected in their terminal part.

The speed of air flow in the tubes was mainly consequence of aircraft speed, but it could be regulated by valves; in the minor tube the flow was slower than in the main one. Each container with predators left aircraft with a speed lower than $28 \mathrm{~m} \mathrm{~s}^{-1}$, and not more than one of them per second was ejected. Release cassette was made of $361(19 \times 19)$ cylindrical chambers (Figure $6 \mathrm{~B})$. The lower part of each chamber was closed by a metal $180 \mu \mathrm{m}$ mesh net, and the top was open; the chamber was then closed by an airtight removable cap. This release system accuracy depends on wind speed, wind direction, and aircraft flight height. A plastic pipette was the container for predators; it was closed by a parafilm plug and a three-leg stopper even working as a counterweight (Figure 6B). A cotton string connected pipette parts and increased the probability for the container to hitch on a plant rather than fall to the ground.

The study was carried out for assessing container characteristics with regard to: the negative effects on parasitoid state, that should be comparable to traditional release; the rapidity of predator release and dispersion on cassava plants; the accuracy for aerial release in small-sized fields. Results were variable in consideration

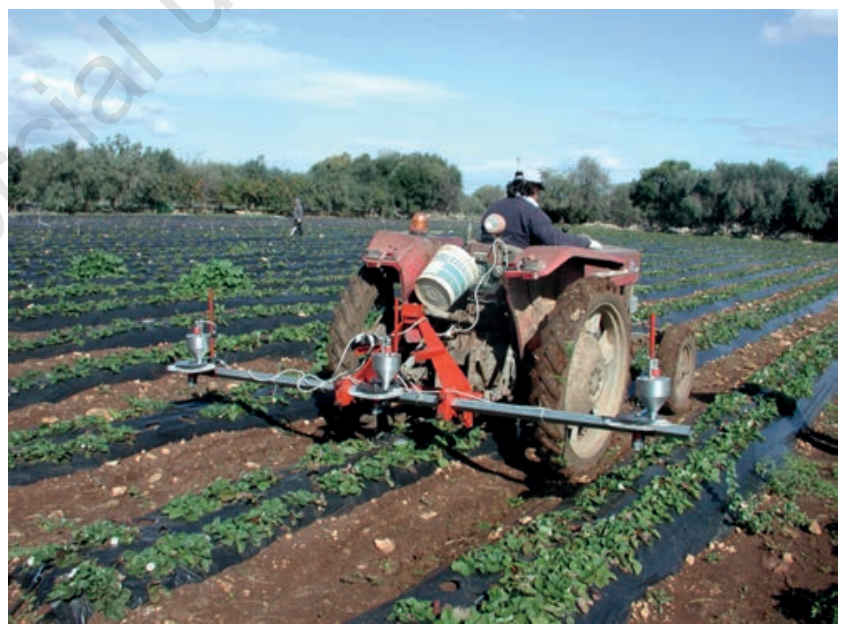

Figure 4. The distributor prototypes of Catania University carried by a tractor (Emma et al., 2010).

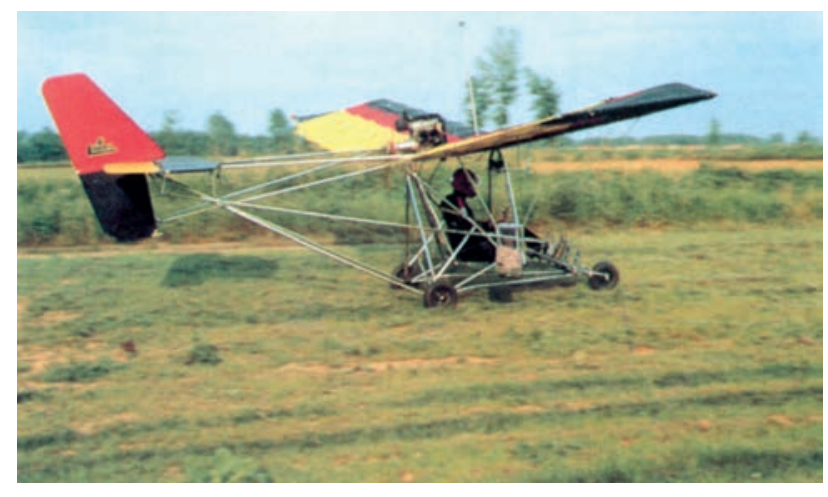

Figure 5. Motor ultralight tested by Maini (Courtesy of Prof. S. Maini). 
of flight height, pilot reflexes, wind speed and direction; but low death rate and losses of predators were observed. Maintaining constant height would make easier distribution in small fields (Drukker et al., 1993).

In 2014, breeder association of Mantova (Italy), its business branch Comal, and Italian subsidiary of Koppert company for organic pest control and natural pollination, developed a drone for contrasting corn borer Ostrinia nubilalis in open fields (Figure 7) (AgriStore, 2017).

The drone was equipped with an automatic dispenser for releasing pyralis natural enemy Trichogramma brassicae; these parasitoid wasps, in the form of eggs, were contained in biodegradable cellulose capsules, that dissolved in contact with the soil, releasing wasp larvae progressively in 15-20 days. The drone, a quadcopter one meter on a side, flew one meter above corn canopy, at a speed of 5-8 $\mathrm{m} \mathrm{s}^{-1}$. It did not have $\mathrm{CO}_{2}$ emissions since it was supplied by a rechargeable battery, and it could fly over 5 hectares before recharging. The drone used field geo-satellite coordinates, operating aerial crossings every $10 \mathrm{~m}$ and moving with a Greek spiral trajectory. Results and costs were comparable to chemical pest management, but distribution could occur with every climatic condition and there were no treading losses (AgroNotizie, 2014; Il Punto Coldiretti, 2014).

Very recently, an unmanned aerial vehicle system (UAVS) was developed, and it was customised to be an alternative tool employed in pest's biological control (Rangel and das Cruzes, 2016). In particular, the generalist parasitoid of moths and butterflies Trichogramma pretiosum was used over soybean crops. The
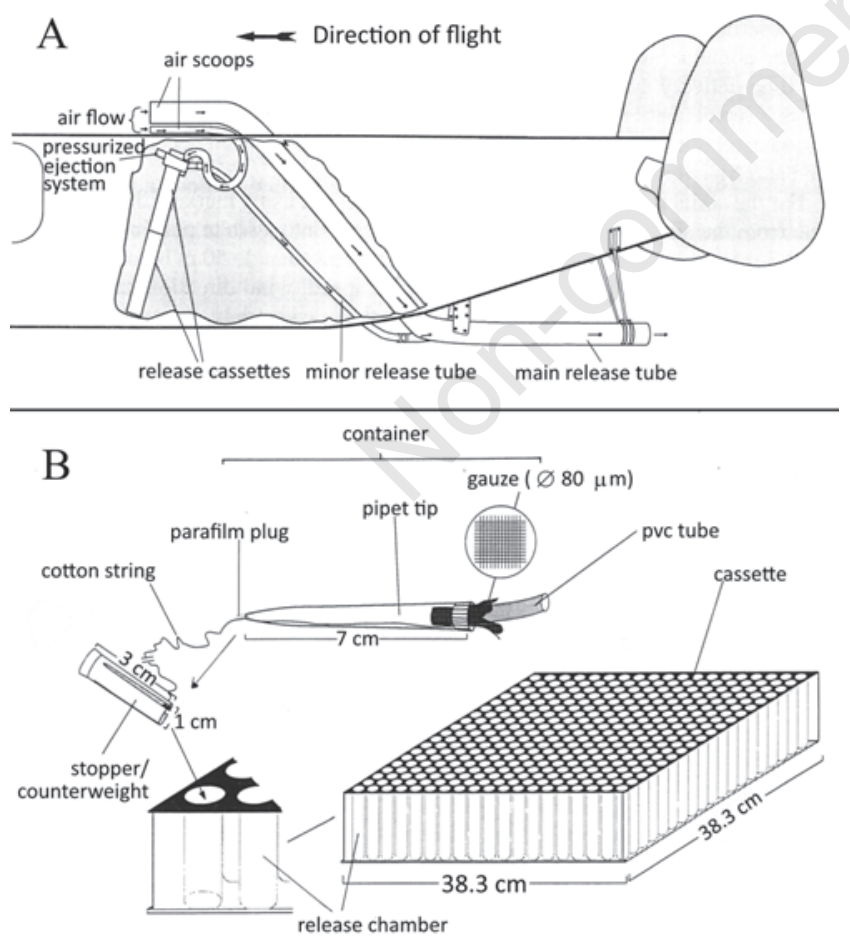

Figure 6. A) AIRS: Airborne Insect Release System; B) release chamber and phytoseiid container. [Panel $B$ reprinted by permission from: Springer Nature; Experimental and Applied Acarology. A packaging and delivery system for aerial release of Phytoseiidae for biological control. B. Drukker, J. S. Yaninek, H. R. Herren; 17 (1993) 129-143. Copyright Springer Nature]. tool tested was an electrical UAVS composed of aircraft, ground station, a specific payload and field support equipment. This system allowed the operator to create pre-defined missions over the crops, setting aircraft route and the points to drop biological agents. Remotely and in real time, the operator could control the aircraft from a one-man portable ground station. The prototype could flight in any atmospheric condition, with a flight autonomy of $60 \mathrm{~min}$. In the ground station, all of the information related to navigation and payload status were showed on a specific and customised screen. In real time, current aircraft position, planned mission (path and waypoints), sensors status and other information were shown, and then the pilot could manage the aircraft's route to correct its position and make changes, if necessary. Payload was equipped with devices that allowed the drop of biological agents over the crops. Starting from the maps generated with the ground station software, the flight plan was created, and the distributed amount was related to the crop status, according to the area degradation indices (e.g. a severe degradation index resulted in a large amount of agents deposited punctually).

Distribution of biological agents occurred autonomously during the UAVS flight, in a previously defined route, unloading small capsules with wasp eggs on the target. Basically, the UAVS took off automatically by a catapult, entered into cruise mode and landed manually. The automatic navigation functions were triggered when the UAVS was flying at cruise speed, which consisted of flying to the target point, keeping the pre-defined route, point after point, throwing the biological agents on target during a specified route, and then returning to the base (return to launched point).

Upon mission ending, the aircraft began the approach for landing process. At this stage, the ground station was warned that the human pilot could take the control of the aircraft. When the pilot had taken the control of the aircraft, the autopilot was switched off and landing stage was performed manually. All of the information obtained during the flight, as well as the aircraft navigation data, images and other related data, were stored in the ground station, thus creating a database for future reference.

Other biological agent's types could be used over other crops considering the same methodology already assessed (Rangel and das Cruzes, 2016).

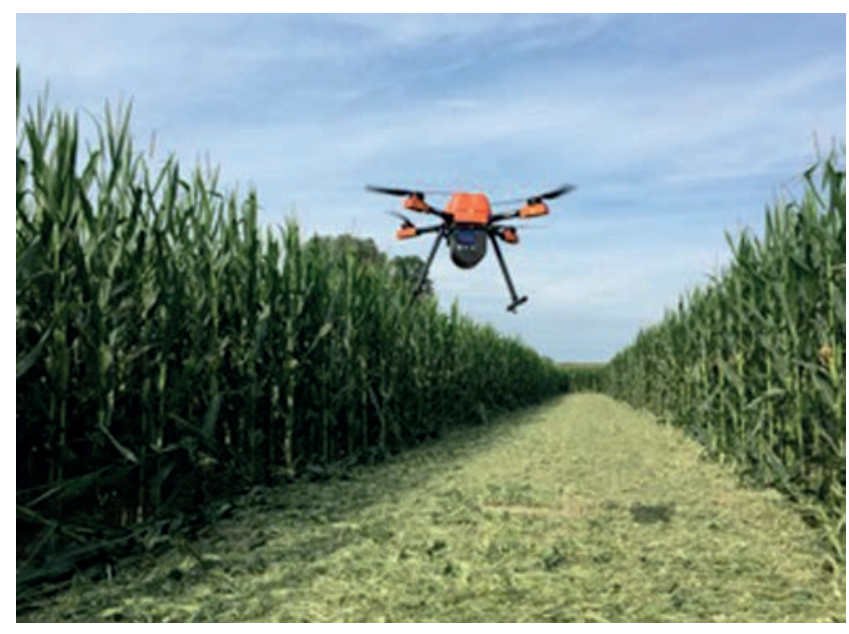

Figure 7. The drone in a corn field (image available publicly from: http://www.agristoresrl.com/droni-agricoltura.php). 


\section{Conclusions}

In the light of the present regulatory trend and the spread of sustainable agricultural practices and organic farming, diffusion of mechanical devices for releasing beneficial organisms could really improve pest management strategies.

Several researches have been carried out in this direction, and different configurations for mechanical, aerial or land distribution, both in greenhouses and open fields, have been assessed. On the whole, natural enemies were not significantly damaged and their releasing was quite uniform; working time, and consequently production costs, were strongly reduced with mechanical throwing, as well as environmental impact when electrical engines were used. The adaptation of spraying technology showed some advantages, such as being already familiar to farming sector, the equipment being easily acquirable, simple application and sound uniformity. Aerial releasing allowed distribution with every climatic condition, while mechanisation in greenhouse reduced the exposure of the operators to its typical uncomfortable and tiring working conditions.

Maybe an additional effort should be done in order to develop machines suitable for different carrier materials and unharmful for various beneficial organisms. But for sure this is a field worthy of interest in the near future.

\section{References}

Agostino M., Fonte M. 2007. Il nuovo regolamento sul biologico dell'Unione Europea. AGRIREGIONIEUROPA, Anno 3, Numero 11, pp 50-3.

AgriStore. 2017. Lotta biologica alla piralide: il drone agricolo. Available from: http://www.agristoresrl.com/droni-agricoltura.php Accessed: April 2017.

AgroNotizie. 2014. Comal, Ama e Koppert insieme contro la piralide grazie ai droni. Available from: http://agronotizie.imagelinenetwork.com/difesa-e-diserbo/2014/06/30/comal-ama-ekoppert-insieme-contro-la-piralide-grazie-ai-droni/38847 Accessed: December 2016.

AgroNotizie. 2015. Biologico, Phil Hogan: "Presto la svolta". Available from: http://agronotizie.imagelinenetwork.com/agricoltura-economia-politica/2015/10/20/biologico-phil-hoganquotpresto-la-svoltaquot/45936 Accessed: April 2017.

Bale J.S., van Lenteren J.C., Bigler F. 2008. Biological control and sustainable food production. Phil. Trans. R. Soc. B 363:761-76.

Berardini L., Ciannavei F., Marino D., Spagnuolo F. 2006. Lo scenario dell'agricoltura biologica in Italia. Working paper SABIO n. 1. Roma, Italy.

Blandini G., Emma G., Failla S., Manetto G. 2007a. Valutazione della distribuzione meccanizzata di antagonisti naturali nelle serre siciliane. pp 39-60 in Proc. Conf. "Strategie di difesa biologica”, Ortomac, Cesena (FC), Italy.

Blandini G., Emma G., Failla S., Manetto G. 2008a. A prototype for mechanical distribution of beneficials. Acta Hort. 801:1515-22.

Blandini G., Emma G., Failla S., Manetto G. 2008b. A new version of prototype for mechanical distribution of natural enemies. pp 1-8 in Proc. Int. Conf. Ragusa SHWA 2008, "Innovation technology to empower safety, health and welfare in agriculture and agro-food systems", Ragusa, Italy.

Blandini G., Emma G., Failla S., Manetto G. 2011. Prestazioni di un prototipo di distributore centrifugo per il rilascio di antago- nisti in pieno campo e in serra. In: A.S. Zarbà (Ed.), La valutazione della difesa biologica come leva di sviluppo competitivo: analisi normativa, tecnica ed economico-agraria. Polistampa, Catania, Italy, pp 57-85.

Blandini G., Emma G., Failla S., Manetto G., Papa R. 2008c. A new version of the prototype for mechanical distribution of beneficials. Conf. on International Research on Food Security, Natural Resource Management and Rural Development, Tropentag 2008, University of Hohenheim, Stuttgart.

Blandini G., Emma G., Failla S., Manetto G., Papa R. 2010. Assessment of centrifugal distribution of natural enemies for the open field. Proc. on USB key Int. Conf. Agric. Engin., Clermont-Ferrand, France.

Blandini G., Failla S., Manetto G. 2007b. Distributore di antagonisti naturali o simili. Brevetto 0001378947, Università degli Studi di Catania, Italy.

Blandini G., Failla S., Manetto G., Tropea Garzia G., Siscaro G., Zappalà L. 2006. Prove preliminari di distribuzione meccanica di antagonisti naturali. Proc. Giornate Fitopatologiche, Riccione (RN), 1:557-62.

Blandini G., Manetto G., Failla S. 2007c. Distributor of natural antagonist or the like. Patent US 8,016,169 B2, Università di Catania, Italy.

Caprara C., Baraldi G., Martelli R., Pezzi F. 2007. Distribuzione meccanica di artropodi nella lotta biologica in colture protette. pp 19-28 in Proc. Conf. "Strategie di difesa biologica", Ortomac, Cesena (FC), Italy.

CREA. 2015. L'agricoltura italiana conta. Consiglio per la ricerca in agricoltura e l'analisi dell'economia agraria, Roma, Italy, pp 137-40.

Drukker B., Yaninek J.S., Herren H.R. 1993. A packaging and delivery system for aerial release of Phytoseiidae for biological control. Exp. Appl. Acarol. 17:129-43.

Emma G., Failla S., Manetto G., Restuccia A. 2010. Mechanical distribution of natural enemies in the open field. pp 479-86 in Proc. Int. Conf. Ragusa SHWA 2010, "Work safety and risk prevention in agro-food and forest systems", Ragusa, Italy.

European Union. 1991. Council Regulation (EEC) No. 2092/91 of 24 June 1991 on organic production of agricultural products and indications referring thereto on agricultural products and foodstuffs. In: Official Journal, L 198, 22/07/1991, pp 1-15.

European Union. 2007. Council Regulation (EC) No. 834/2007 on organic production and labelling of organic products and repealing Regulation (EEC) No. 2092/91. In: Official Journal, L 189, 20/07/2007, pp 1-23.

European Union. 2008a. Commission Regulation (EC) No. $889 / 2008$ laying down detailed rules for the implementation of Council Regulation (EC) No. 834/2007 on organic production and labelling of organic products with regard to organic production, labelling and control. In: Official Journal, L 250, 18/09/2008, pp 1-84.

European Union. 2008b. Commission Regulation (EC) No. 1235/2008 laying down detailed rules for implementation of Council Regulation (EC) No. 834/2007 as regards the arrangements for imports of organic products from third countries. In: Official Journal, L 334, 12/12/2008, pp 25-52.

European Union. 2008c. Commission Regulation (EC) No. 1254/2008 amending Regulation (EC) No. 889/2008 laying down detailed rules for implementation of Council Regulation (EC) No. 834/2007 on organic production and labelling of organic products with regard to organic production, labelling and control. In: Official Journal, L 337, 16/12/2008, pp 80-2.

European Union. 2009a. Directive 2009/127/EC of the European 
Parliament and of the Council of 21 October 2009 amending Directive 2006/42/EC with regard to machinery for pesticide application. In: Official Journal, L 310, 25/11/2009, pp 29-33.

European Union. 2009b. Directive 2009/128/EC of the European Parliament and of the Council of 21 October 2009 establishing a framework for Community action to achieve the sustainable use of pesticides. In: Official Journal, L 309, 24/11/2009, pp 71-86.

Failla S., Manetto G., Restuccia A. 2012. Organic plant protection treatments in greenhouse and open field by an electrical prototype. pp 491-9 in Proc. Int. Conf. Ragusa SHWA 2012, "Safety health and welfare in agriculture and in agro-food systems", Ragusa, Italy.

Gan-Mor S., Matthews G.A. 2003. Recent developments in sprayers for application of biopesticides - an overview. Biosyst. Eng. 84:119-25.

Gardner J., Giles K. 1996. Handling and environmental effects on viability of mechanically dispensed green lacewing eggs. Biol. Control 7:245-50.

Gardner J., Giles K. 1997. Mechanical distribution of Chrysoperla rufilabris and Trichogramma pretiosum: survival and uniformity of discharge after spray dispersal in an aqueous suspension. Biol. Control. 8:138-42.

Giles D.K., Gardner J., Studer H.E. 1995. Mechanical release of predacious mites for biological pest control in strawberries. T. ASAE 38:1289-96.

Il Punto Coldiretti. 2014. Arriva il drone contro la piralide del mais. Available from: http://www.ilpuntocoldiretti.it/attualita/Pagine/Arrivaildronecontrolapiralidedelmais.aspx Accessed: April 2017.

INEA. 2002. L'agricoltura italiana conta. Istituto Nazionale di Economia Agraria, Roma, Italy, pp 112-4.

INEA. 2006. L'agricoltura italiana conta. Istituto Nazionale di Economia Agraria, Roma, Italy, pp 64-8.

INEA. 2012. L'agricoltura italiana conta. Istituto Nazionale di Economia Agraria, Roma, Italy, pp 121-4.

ISTAT. 2000, 2005, 2010, 2015. Available from: http://agri.istat.it/sag_is_pdwout/jsp/Introduzione.jsp?id=15A Accessed: April 2016.

Lamichhane J.R. 2017. Pesticide use and risk reduction in European farming systems with IPM: An introduction to the special issue. Crop Prot. 97:1-6.

Lanzoni A., Burgio G., Maini S. 2007. Prove di lancio meccanico di Phytoseiulus persimilis e Orius laevigatus in colture protette. Proc. Conf. "Strategie di difesa biologica", Ortomac, Cesena (FC), Italy, pp 29-38.

Lanzoni A., Martelli R., Pezzi F. 2017. Mechanical release of Phytoseiulus persimilis and Amblyseius swirskii on protected crops. B. Insectol. 70:245-50.

Maini S., Burgio G. 2000. I trichogramma. In: G. Nicoli, P. Radeghieri, Gli ausiliari nell'agricoltura sostenibile. Calderini Edagricole, Bologna, Italy, pp 135-43.

Maini S., Gattavecchia C., Libè A. 1988. Impiego di velivolo ultraleggero per lanci di Trichogramma maidis Pint. e Voeg. contro Ostrinia nubilalis ( $\mathrm{Hb}$.). Proc. Giornate Fitopatologiche,
2:203-12.

Mul M.F., Ploegaert J.P.M., George D.R., Meerburg B.G., Dicke M., Koerkamp P.W.G.G. 2016. Structured design of an automated monitoring tool for pest species. Biosyst. Eng. 151:126-40.

National Rural Network 2007-2013. 2012. BIOREPORT 2012, Organic farming in Italy. Available from: https://www.reterurale.it/flex/cm/pages/ServeBLOB.php/L/EN/IDPagina/10616 Accessed: March 2016.

Opit G.P., Nechols J.R., Margolies D.C., Williams K.A. 2005. Survival, horizontal distribution, and economics of releasing predatory mites (Acari: Phytoseiidae) using mechanical blowers. Biol. Control 33:344-51.

Pezzi F., Baraldi G., Martelli R., Caprara C. 2007. Meccanizzazione per la difesa biologica. Mondo Macchina 16:26-30.

Pezzi F., Martelli R., Lanzoni A., Maini S. 2015. Effects of mechanical distribution on survival and reproduction of Phytoseiulus persimilis and Amblyseius swirskii. Biosyst. Eng. 129:11-9.

Pezzi F., Rondelli V., Baraldi G. 2002. Mechanical distribution of Phytoseiids in greenhouse crops. Riv. Ing. Agr. 33:33-9.

Pickett C.H., Gilstrap F.E., Morrison R.K., Bouse L.F. 1987. Release of predatory mites (Acari: Phytoseiidae) by aircraft for the biological control of spider mites (Acari: Tetranychidae) infesting corn. J. Econ. Entomol. 80:906-10.

Rangel R.K., das Cruzes M. 2016. Development of an UAVS distribution tools for pest's biological control "Bug Bombs!". IEEE Aerospace Conference, Montana, USA, pp 1-8.

Rete Rurale Nazionale 2007-2013. 2015. Bioreport 2014-2015. L'agricoltura biologica in Italia. Roma. Available from: https://www.reterurale.it/flex/cm/pages/ServeBLOB.php/L/IT/ IDPagina/15590 Accessed: May 2016.

SINAB. 2000. Bio in cifre 2000. Sistema d'Informazione Nazionale sull'Agricoltura Biologica, Roma, Italy.

SINAB. 2005. Bio in cifre 2005. Sistema d'Informazione Nazionale sull'Agricoltura Biologica, Roma, Italy.

SINAB. 2010. Bio in cifre 2010. Sistema d'Informazione Nazionale sull'Agricoltura Biologica, Roma, Italy.

SINAB. 2015. Bio in cifre 2015. Sistema d'Informazione Nazionale sull'Agricoltura Biologica, Roma, Italy.

Tropea Garzia G., Failla S., Manetto G., Siscaro G., Zappalà L. 2012. Mechanical release of Phytoseiulus persimilis and Orius laevigatus on protected crops. IOBC-WPRS Bull. 80:253-9.

Wright M.G. 2014. Biological control of invasive insect pests. In: D.P. Abrol (Ed.), Integrated pest management - current concepts and ecological perspective. Elsevier Science Publishing Co. Inc., Amsterdam, The Netherlands, pp 267-81.

Wunderlich L.R., Giles D.K. 1999. Field assessment of adhesion and hatch of Chrysoperla eggs mechanically applied in liquid carriers. Biol. Control 14:159-67.

Zappalà L., Manetto G., Tropea Garzia G., Emma G., Failla S. 2012. Mechanical distribution of Phytoseiulus persimilis on chrysanthemum. Acta Hort. 952:793-800. 